DOE STTR DE-FG02-08ER86337: Topic “Nanotechnology”, Subtopic 12d - ALD NanoSolutions, Inc.

"Novel ALD-coated Nanoparticle Anodes for Enhanced Performance Lithium-Ion Batteries"

\title{
Novel ALD-Coated Nanoparticle Anodes for Enhanced Performance Lithium-Ion Batteries
}

Topic 12 "Nanotechnology"

Subtopic 12d "Nanomaterials for Lithium-Ion Batteries Used in Energy Storage"

Grant Number: DE-FG02-08ER86337

PI: Dr. Markus Groner

ALD NanoSolutions, Inc.

580 Burbank St., Unit 100

Broomfield, CO 80020 
DOE STTR DE-FG02-08ER86337: Topic “Nanotechnology”, Subtopic 12d - ALD NanoSolutions, Inc.

"Novel ALD-coated Nanoparticle Anodes for Enhanced Performance Lithium-Ion Batteries"

\section{Executive Summary}

The Phase I effort is described in detail in the Phase I report given below. In this section, we will briefly highlight the achievements from the Phase I project that motivate the Phase II project. The key accomplishments of the Phase I project were (1) the demonstration of high stability $\mathrm{LiCoO}_{2}$ cathodes using ALD-coated $\mathrm{LiCoO}_{2}$ particles, as well as on ALD-coated $\mathrm{LiCoO}_{2}$ electrodes and (2) the demonstration of high stability graphite anodes using ALD-coated graphite electrodes.

The ultrathin ALD coatings produced much more stable capacity for half-cells prepared using $\mathrm{Al}_{2} \mathrm{O}_{3} \mathrm{ALD}$-coated $\mathrm{LiCoO}_{2}$ particles. Battery cathodes were prepared and cycled against a $\mathrm{Li} / \mathrm{Li}^{+}$anode near the threshold for $50 \% \mathrm{Li}$ extraction at $1 \mathrm{C}$-rate after the first two chargedischarge cycles. With respect to the third charge-discharge cycle, the $\mathrm{LiCoO}_{2}$ particles coated with $2 \mathrm{Al}_{2} \mathrm{O}_{3}$ ALD cycles showed a $89 \%$ capacity retention after 120 charge-discharge cycles as shown in Figure 4. In comparison, the bare $\mathrm{LiCoO}_{2}$ particles displayed only a $45 \%$ capacity retention after 120 charge-discharge cycles.

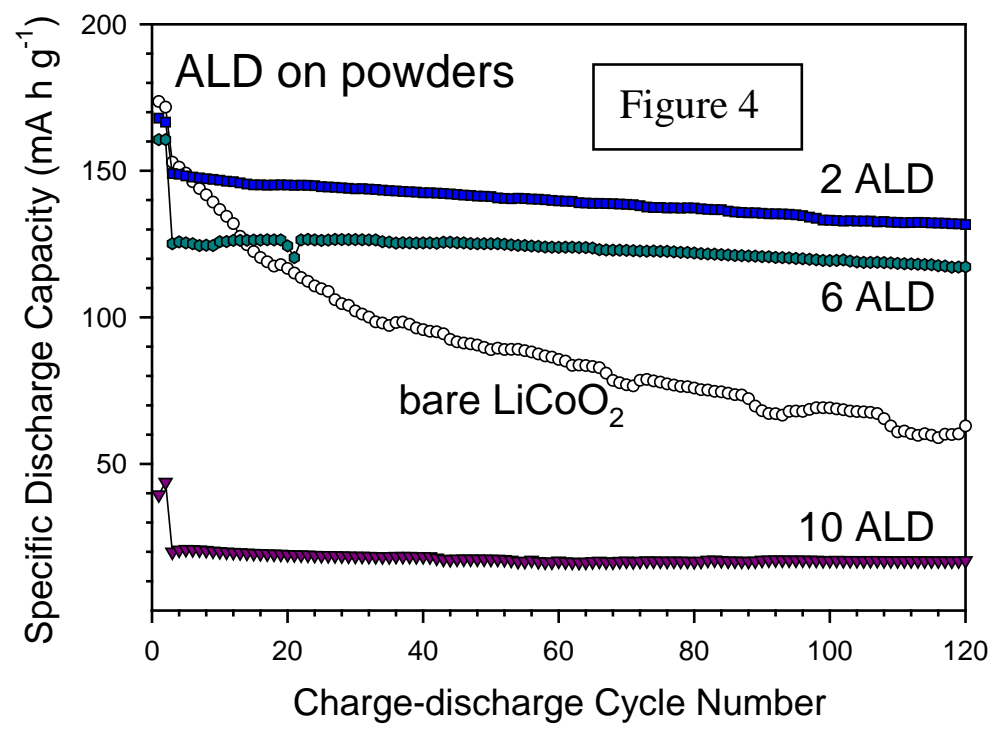

The $\mathrm{Al}_{2} \mathrm{O}_{3}$ ALD may enhance the cycle performance of the half-cells by a number of mechanisms. The $\mathrm{Al}_{2} \mathrm{O}_{3}$ film may prevent the $\mathrm{LiCoO}_{2}$ particles from decomposing electrolyte and forming a solid-electrolyte interphase. Alternatively, the $\mathrm{Al}_{2} \mathrm{O}_{3}$ film may protect the $\mathrm{LiCoO}_{2}$ particles from corrosion by HF. Figure 4 also shows that $\mathrm{LiCoO}_{2}$ particles coated with 6 and $10 \mathrm{Al}_{2} \mathrm{O}_{3}$ ALD cycles showed lower specific capacities when run at a $1 \mathrm{C}$-rate after the first two charge-discharge cycles. This lower capacity is attributed to the

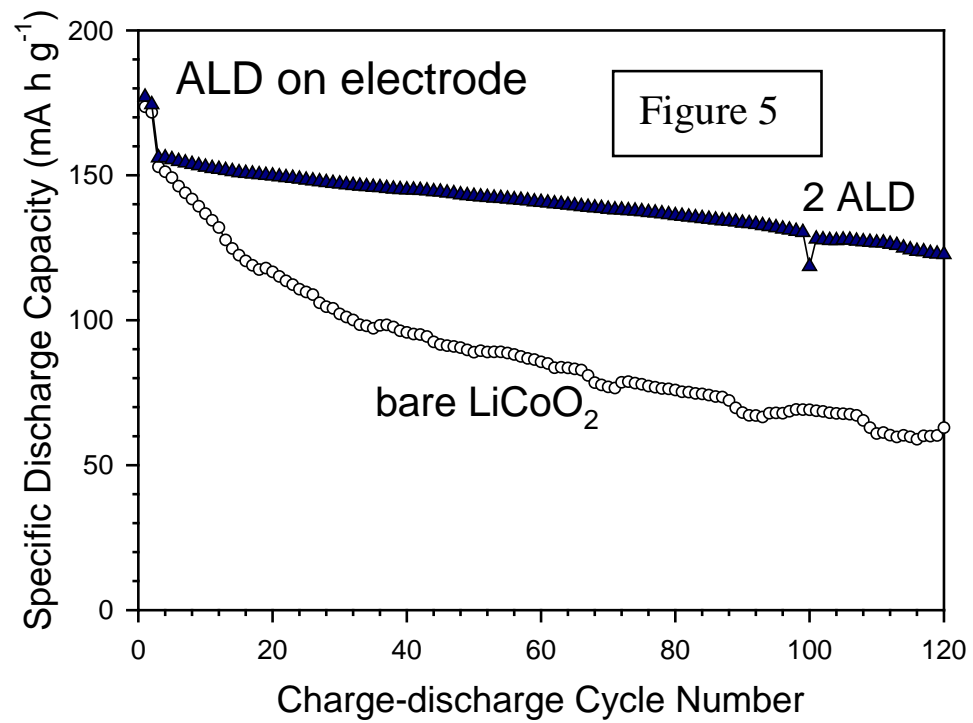
slower $\mathrm{Li}^{+}$diffusion and restricted electron mobility through the insulating $\mathrm{Al}_{2} \mathrm{O}_{3} \mathrm{ALD}$ layer.

The enhanced capacity for the $\mathrm{LiCoO}_{2}$ particles coated with only 2 ALD cycles is exceptional. The $\mathrm{Al}_{2} \mathrm{O}_{3}$ ALD film thickness deposited using 2 ALD cycles is only $\sim 2.5 \AA$. This ultrathin thickness represents only approximately one atomic layer of the $\mathrm{Al}_{2} \mathrm{O}_{3} \mathrm{ALD}$ coating. 
DOE STTR DE-FG02-08ER86337: Topic “Nanotechnology”, Subtopic 12d - ALD NanoSolutions, Inc.

"Novel ALD-coated Nanoparticle Anodes for Enhanced Performance Lithium-Ion Batteries"

This ultrathin thickness is able to alter dramatically the interaction of the $\mathrm{LiCoO}_{2}$ particles and the electrolyte forming the half-cell. Additional experiments were conducted where the $\mathrm{LiCoO}_{2}$ particles were first used to make electrodes prior to ALD coating. These experiments also yielded significant improvements. Figure 5 shows the capacity versus number of chargedischarge cycles for electrodes coated with 2 cycles of $\mathrm{Al}_{2} \mathrm{O}_{3}$ ALD and uncoated electrodes prepared using $\mathrm{LiCoO}_{2}$ particles. The ALD-coated electrodes displayed much more stable capacity.

Experiments were also conducted using $\mathrm{Al}_{2} \mathrm{O}_{3}$ ALD to coat graphite particles and graphite electrodes. These investigations yielded very dramatic results. Compared with the bare graphite particles, Figure 6 reveals that the $\mathrm{Al}_{2} \mathrm{O}_{3}$ ALD directly on the graphite particles reduced the capacity in halfcell tests versus charge-discharge cycle number. This reduction is attributed to the insulating nature of the $\mathrm{Al}_{2} \mathrm{O}_{3}$ ALD coating. In contrast, the $\mathrm{Al}_{2} \mathrm{O}_{3}$ ALD coated on the electrodes prepared using the uncoated graphite particles led to spectacular improvement in

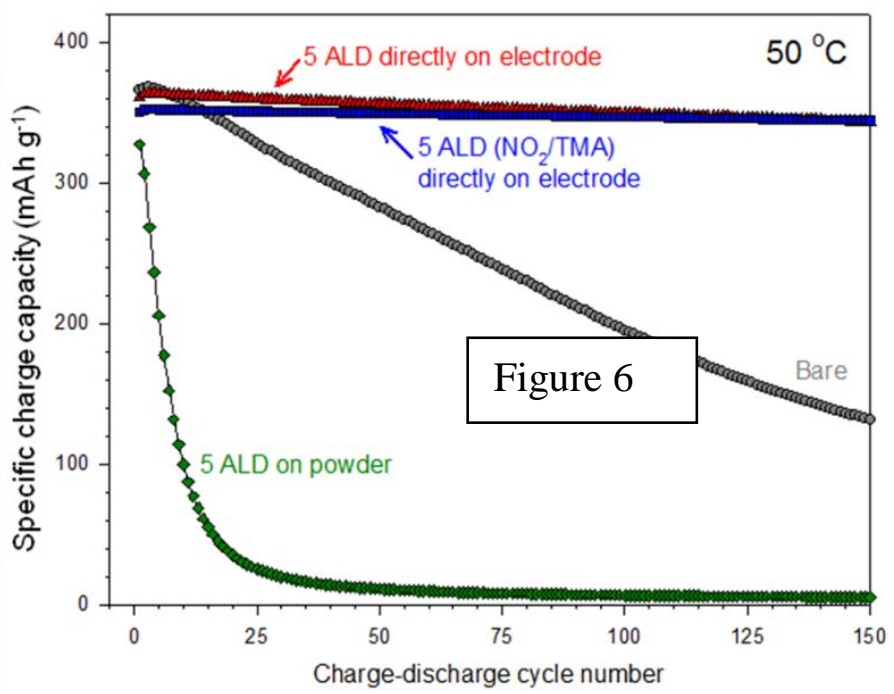
performance. The capacity of the ALD-coated graphite electrodes was almost unchanged after 200 charge-discharge cycles at $50^{\circ} \mathrm{C}$ as shown in Figure 6.

The difference between the electrodes prepared using ALD-coated graphite particles and electrodes fabricated using ALD to coat the formed graphite electrodes may result from the different electron mobilities. In the electrodes prepared using the $\mathrm{Al}_{2} \mathrm{O}_{3}$-coated graphite particles, electron mobility is reduced by every $\mathrm{Al}_{2} \mathrm{O}_{3}$ ALD junction between the graphite particles. In the electrodes fabricated using ALD to coat the formed graphite electrode, the $\mathrm{Al}_{2} \mathrm{O}_{3}$ ALD coats only the graphite surface exposed to the gas phase

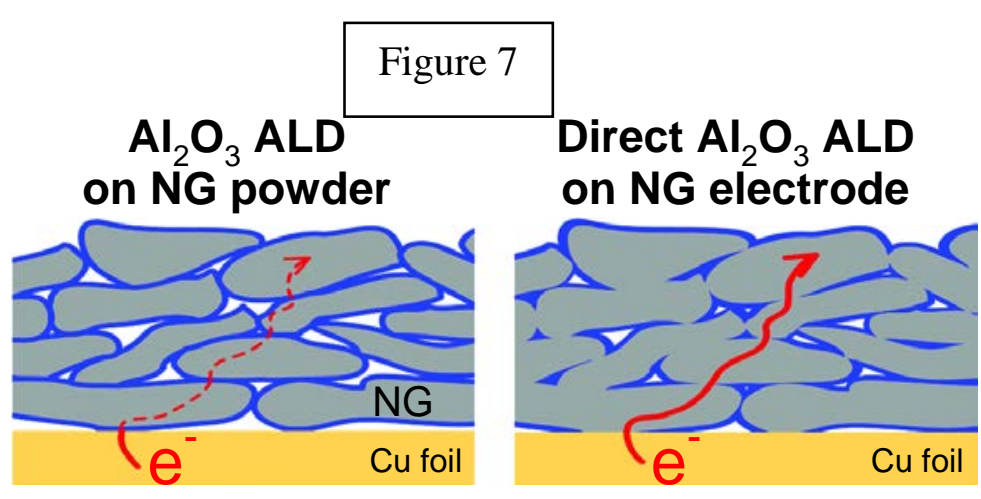
precursors. The electron paths between the contacting graphite particles are not affected because the $\mathrm{Al}_{2} \mathrm{O}_{3}$ ALD could not coat the areas between the contacting particles. These two situations are illustrated by Figure 7 .

In addition, the $\mathrm{Al}_{2} \mathrm{O}_{3} \mathrm{ALD}$ coating on the formed graphite electrodes allowed propylene carbonate (PC) to be used in the electrolyte. PC is essential for operating Li- ion batteries at low temperatures resulting from the low melting point for PC of $-49^{\circ} \mathrm{C}$. Voltage measurements versus charging and discharging revealed that bare graphite is electrochemically exfoliated by 
DOE STTR DE-FG02-08ER86337: Topic “Nanotechnology”, Subtopic 12d - ALD NanoSolutions, Inc. "Novel ALD-coated Nanoparticle Anodes for Enhanced Performance Lithium-Ion Batteries"

PC-based electrolytes. In contrast, graphite electrodes coated with 5 cycles of $\mathrm{Al}_{2} \mathrm{O}_{3}$ ALD reversibly reacts with Li without any evidence of exfoliation. To our best knowledge, there are no reports of any other coating that can lead to the compatibility of graphite with PC-based electrolytes. This compatibility is particularly important for the cold weather operation of HEVs. 
DOE STTR DE-FG02-08ER86337: Topic “Nanotechnology”, Subtopic 12d - ALD NanoSolutions, Inc.

"Novel ALD-coated Nanoparticle Anodes for Enhanced Performance Lithium-Ion Batteries"

\section{A. Introduction}

This Phase I STTR program has demonstrated that ALD coatings can significantly improve the stability of graphite and nano- $\mathrm{MoO}_{3} \mathrm{Li}$-ion battery anodes. These results were achieved using only sub-nanometer thick ALD coatings. Similar ALD coatings were also able to greatly improve the performance of commercial $\mathrm{LiCoO}_{2}$ materials. In addition to extensive halfcell testing and characterization of ALD coated battery powders and electrodes, a full cell battery was also fabricated based on the most promising anode and cathode half cell testing results. This ALD coated natural graphite/ $\mathrm{LiCoO}_{2}$ battery showed greatly improved capacity retention over 200 charge/discharge cycles compared to a battery fabricated from uncoated materials.

ALD NanoSolutions, Inc. worked closely with the University of Colorado (CU), NREL, and commercial partners to demonstrate the promise of these ALD coatings. Small batch ALD coatings were performed at the Prof. Steven George lab at CU, while large batch coating, primarily as requested by commercial partners, were performed in pilot scale fluid bed reactors at ALD NanoSolutions, Inc. Battery testing was carried out by the Prof. Se-Hee Lee lab at CU and by commercial partners. Electrode materials were obtained from NREL and from commercial sources.

Although the focus of the project was on anode materials, the great results on the anode materials led to the examination of wide array of ALD coatings and electrode materials. By expanding the scope of the project beyond its original goals, we were able to show additional promising applications for ALD coatings and attract further commercial interest.

These encouraging results support the underlying premise that ALD coatings can be custom-tailored for various battery materials in order to improve stability. These surface coatings can lead to a variety of benefits including increased capacity retention, improved rate capacity, higher voltage charging, and enhanced safety.

\section{B. ALD coatings of Li-ion battery materials}

The coating of battery powders using ALD was performed using fluidized bed reactors at ALD NanoSolutions Inc and rotary reactors at the University of Colorado (CU). Both reactor designs are inherently scalable technologies, but in this study the coating of small batches (up to $\sim 5 \mathrm{~g}$ ) were performed at CU, while large batches (100s of grams to kilograms) were coated at ALD NanoSolutions. In addition, ALD coatings on fabricated electrodes were performed in a conventional ALD reactor.

The pilot scale fluid bed reactor at ALD NanoSolutions has a capacity of up to 2 liters of powder. The particles are contained in a $\sim 6$ " diameter, temperature controlled metal tube, with a porous metal plate at the bottom and filters at the top. Fluidization is achieved by flowing inert nitrogen gas up trough the particle bed while monitoring the pressure drop. In order to conformally coat the particles by ALD, the precursor gases are alternately flowed through the particle bed (while the nitrogen flow is reduced to maintain fluidization conditions). For $\mathrm{Al}_{2} \mathrm{O}_{3}$ ALD, one ALD cycle consists of: 1) Dosing TMA through reactor, 2) Flowing $\mathrm{N}_{2}$ only to purge methane product and any excess TMA reactant, 3) Dosing water, and 4) Flowing $\mathrm{N}_{2}$. The exhaust gases are monitored with a residual gas analyzer (RGA) mass spectrometer to determine the endpoint of each reaction and also to determine how to purge the particle bed between the ALD reactions. The RGA allows the precursor usage efficiencies approaching $100 \%$. 
DOE STTR DE-FG02-08ER86337: Topic “Nanotechnology”, Subtopic 12d - ALD NanoSolutions, Inc. "Novel ALD-coated Nanoparticle Anodes for Enhanced Performance Lithium-Ion Batteries"

In the rotary ALD reactors at $\mathrm{CU}$, the powders are contained in a porous metal drum that is being slowly rotated inside of a chamber, while the precursor gases are alternately introduced and purged. For the $\mathrm{Al}_{2} \mathrm{O}_{3} \mathrm{ALD}$, the precursors are trimethylaluminum (97\%) and HPLC grade $\mathrm{H}_{2} \mathrm{O}$, obtained from Sigma-Aldrich. The $\mathrm{Al}_{2} \mathrm{O}_{3}$ ALD reaction sequence was: (1) TMA dose to 1.0 Torr; (2) TMA reaction time; (3) evacuation of reaction products and excess TMA; (4) $\mathrm{N}_{2}$ dose to 20.0 Torr; (5) $\mathrm{N}_{2}$ static time; (6) evacuation of $\mathrm{N}_{2}$ and any entrained gases; (7) $\mathrm{H}_{2} \mathrm{O}$ dose to 1.0 Torr, (8) $\mathrm{H}_{2} \mathrm{O}$ reaction time; (9) evacuation of reaction products and excess $\mathrm{H}_{2} \mathrm{O}$; (10) dose N2; (11) $\mathrm{N}_{2}$ static time; and (12) evacuation of $\mathrm{N}_{2}$ and any entrained gases. This sequence constitutes one $\mathrm{AB}$ cycle of $\mathrm{Al}_{2} \mathrm{O}_{3} \mathrm{ALD}$. In this reactor, 1 minute dose and purge times were typical. ALD was conducted at $180^{\circ} \mathrm{C}$, The typical growth rate for this chemistry is $0.12 \mathrm{~nm}$ per ALD cycle.

For coatings on graphite, the $\mathrm{Al}_{2} \mathrm{O}_{3}$ ALD process was sometimes preceded by an $\mathrm{NO}_{2}$ nucleation treatment that is designed to enhance the reactivity of the graphite. An adsorbed functionalization layer was formed on the NG by alternating exposures of $\mathrm{NO}_{2}$ (99.5\%-Airgas) and TMA:
(A)
$\mathrm{NG}^{*}+\mathrm{NO}_{2}$
$\rightarrow \quad \mathrm{NG}-\mathrm{NO}_{2} *$
(B) NG- $\mathrm{NO}_{2} *+\mathrm{TMA}$
$\mathrm{NG}-\mathrm{NO}_{2} *-\mathrm{TMA}^{*}$

Upon TMA exposure, the oxygen atoms coordinate to the aluminum of the TMA molecule leaving a methyl-terminated surface. The methyl-terminated surface does not interact with subsequent $\mathrm{NO}_{2}$ exposures. Since one cycle of this process may not fully functionalize the surface, 10 cycles of $\mathrm{NO}_{2}$ /TMA were used in this work.

Electrodes were coated in the same reactor (without the rotating porous metal drum), using similar dosing conditions as the powders. The electrodes were pieces of metal foils with a layer of electrode powder on them, as described in more detail later.

The ALD coating runs performed for this work focused on anode materials, including graphite and $\mathrm{MoO}_{3}$. In addition, we also applied ALD coatings to cathode materials, as this was of interest to our commercial partners. Overall, this project involved dozens of coating runs on a variety of commercial materials as well as on experimental battery materials, such as nano$\mathrm{MoO}_{3}$ and nano-Si. This broad survey of electrode materials and ALD coatings expanded the scope of the program far beyond the originally proposed study, and the encouraging results have already led to interest in commercialization of this technology. Table 1 below shows the numerous ALD coating runs that were performed on a variety of electrode powders as well as on fabricated electrodes. 
DOE STTR DE-FG02-08ER86337: Topic “Nanotechnology”, Subtopic 12d - ALD NanoSolutions, Inc.

"Novel ALD-coated Nanoparticle Anodes for Enhanced Performance Lithium-Ion Batteries"

Table 1: Summary of ALD coating runs during phase I

\begin{tabular}{|c|c|c|c|c|}
\hline Anodes & Source & Coating & ALD Cycles & Comments \\
\hline \multicolumn{5}{|l|}{$\overline{\mathrm{MoO}_{3}}$} \\
\hline Nanopowder & NREL 5-20 nm & $\mathrm{Al}_{2} \mathrm{O}_{3}$ & 5,10 & \\
\hline Electrode & NREL 5-20 nm & $\mathrm{Al}_{2} \mathrm{O}_{3}$ & 2,4 & \\
\hline Nanopowder & NREL 5-20 nm & $\mathrm{TiO}_{2}$ & $2, ?$ & \\
\hline Powder & NREL $\sim 5 \mu \mathrm{m}$ & $\mathrm{Al}_{2} \mathrm{O}_{3}$ & $2,5,10,50$ & \\
\hline \multicolumn{5}{|l|}{ Graphite } \\
\hline Powder & NFG3429 $30 \mu \mathrm{m}$ & $\mathrm{Al}_{2} \mathrm{O}_{3}$ & 5,10 & w/o $\mathrm{NO}_{2}$ treatment \\
\hline Powder & NFG-HPM850 $5 \mu \mathrm{m}$ & $\mathrm{Al}_{2} \mathrm{O}_{3}$ & $2,5,10,20,50$ & $\mathrm{w} / \mathrm{o} \mathrm{NO}$ treatment \\
\hline Electrode & NFG-HPM850 $5 \mu \mathrm{m}$ & $\mathrm{Al}_{2} \mathrm{O}_{3}$ & $2,5,20,50$ & $\mathrm{w} / \mathrm{o} \mathrm{NO}_{2}$ treatment \\
\hline \multirow[t]{3}{*}{$\begin{array}{l}\text { Micron } \\
\text { powder }\end{array}$} & $\begin{array}{l}\text { Superior Graphite } \\
\text { LBG8004 }\end{array}$ & $\mathrm{Al}_{2} \mathrm{O}_{3}$ & 5,10 & \\
\hline & “ & $\mathrm{TiO}_{2}$ & 5,10 & \\
\hline & “ & TiN & $5,10,30$ & ALD difficult, XPS \\
\hline \multirow[t]{2}{*}{$\begin{array}{l}\text { Micron } \\
\text { powder }\end{array}$} & $\begin{array}{l}\text { Conoco Phillips } \\
\text { Cpreme G5 }\end{array}$ & $\mathrm{Al}_{2} \mathrm{O}_{3}$ & 2,5 & \\
\hline & “ & $\mathrm{TiO}_{2}$ & 5,10 & \\
\hline Powder & $\begin{array}{l}\text { Meso-Carbon } \\
\text { microbeads MCMB }\end{array}$ & $\mathrm{Al}_{2} \mathrm{O}_{3}$ & 10,20 & TEM, w/o $\mathrm{NO}_{2}$ \\
\hline \multicolumn{5}{|l|}{$\mathrm{TiO}_{2}$} \\
\hline Powder & $020409 \mathrm{TiO}_{2} \mathrm{~B}$ & $\mathrm{RuO}_{2}$ & $1,2,5$ & XPS \\
\hline \multicolumn{5}{|l|}{ Si } \\
\hline Nanopowder & & $\mathrm{Al}_{2} \mathrm{O}_{3}$ & 5 & \\
\hline
\end{tabular}

\begin{tabular}{|c|c|c|c|c|}
\hline Cathodes & Source & Coating & ALD Cycles & Comments \\
\hline \multicolumn{5}{|l|}{$\mathrm{LiCoO}_{2}$} \\
\hline \multirow[t]{2}{*}{ Powder } & $\begin{array}{l}\text { LICO Tech, L106 } \\
\text { 7-10 } \mu \mathrm{m}\end{array}$ & $\mathrm{Al}_{2} \mathrm{O}_{3}$ & $2,4,6,8,10,20,100$ & XPS \\
\hline & “ & $\mathrm{ZnO}$ & $2,4,10$ & XPS, ZnO dissolved \\
\hline Electrode & $\begin{array}{l}\text { LICO Tech, L106 } \\
7-10 \mu \mathrm{m}\end{array}$ & $\mathrm{Al}_{2} \mathrm{O}_{3}$ & $2,4,20$ & \\
\hline Powder & Commercial partner & $\mathrm{Al}_{2} \mathrm{O}_{3}$ & 2,4 & BET \\
\hline \multirow[t]{2}{*}{ Powder } & Aldrich & $\mathrm{Al}_{2} \mathrm{O}_{3}$ & 2,4 & \\
\hline & " & $\mathrm{RuO}_{2}$ & $2,4,10$ & \\
\hline \multicolumn{5}{|l|}{$\mathrm{LiMnO}_{2}$} \\
\hline Powder & & $\mathrm{Al}_{2} \mathrm{O}_{3}$ & 2,10 & \\
\hline \multicolumn{5}{|l|}{$\mathrm{LNCAO}_{2}$} \\
\hline Powder & & $\mathrm{Al}_{2} \mathrm{O}_{3}$ & 10 & \\
\hline
\end{tabular}

The characterization of ALD films grown on these particles and elctrodes included XPS analysis, BET surface area, and TEM imaging. TEM images of ALD coated graphites were 
DOE STTR DE-FG02-08ER86337: Topic “Nanotechnology”, Subtopic 12d - ALD NanoSolutions, Inc. "Novel ALD-coated Nanoparticle Anodes for Enhanced Performance Lithium-Ion Batteries"

obtained, but it was not possible to distinguish between the ALD films and the graphite. In part this was due to the irregular nature of the graphite surfaces, and in part to the very thin (nanometer and sub-nanometer) thicknesses of the ALD films. (In the past, we have successfully obtained TEM and SEM images of ALD coated particles, which confirmed the excellent conformality and smoothness of our ALD coatings. Typically those film thicknesses were on the order of tens of nanometers.)

XPS analysis proved to be the most useful technique for analyzing these very thin ALD films. In the case of TiN ALD coatings (which are difficult to do by ALD), XPS was used to confirm that there was $\mathrm{Ti}$ and $\mathrm{N}$ on the surface of the graphite, and that these amounts increased with number of ALD cycles. For the $\mathrm{Al}_{2} \mathrm{O}_{3}$ ALD coatings on $\mathrm{LiCoO}_{2}$, XPS was able to establish the conformality of the coatings. Figure 10b shows the $\mathrm{Al}$ and $\mathrm{Co}$ atomic fraction as determined by X-ray photoelectron spectroscopy (XPS) in Figure 10a. The rapid attenuation of the $\mathrm{Al}$ signal is evidence that the $\mathrm{Al}_{2} \mathrm{O}_{3} \mathrm{ALD}$ is conformally coating the $\mathrm{LiCoO}_{2}$ particles.
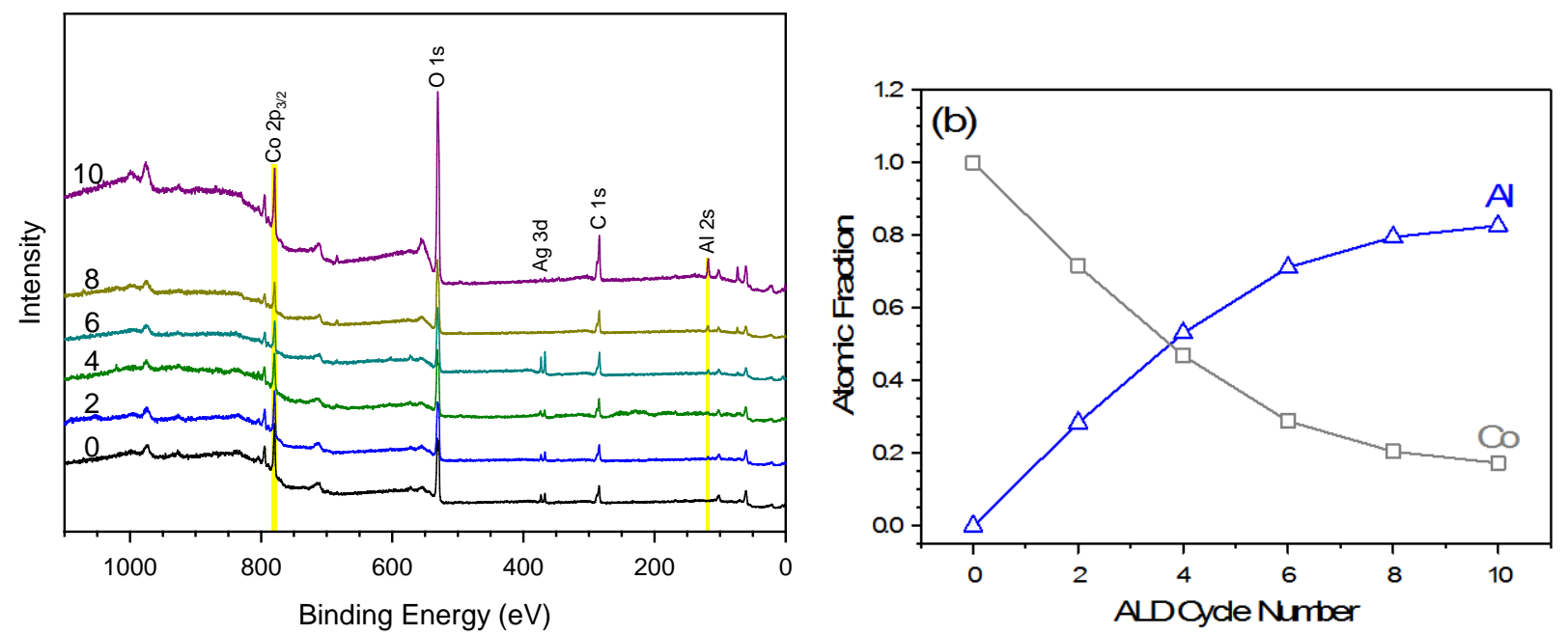

This XPS data was also used to estimate a growth rate by modeling the attenuation of the Co signal vs. the number of $\mathrm{Al}_{2} \mathrm{O}_{3}$ ALD cycles. The growth rate of $\sim 0.2 \mathrm{~nm}$ per ALD cycle is a little higher than the typical growth rate for this chemistry of $0.12 \mathrm{~nm}$ per cycle. However, this model assumes growth on a flat surface. Also, a slightly higher growth rate could have resulted if the $\mathrm{H}_{2} \mathrm{O}$ was not completely purged from this high surface area powder, resulting in limited CVD. This issue can be eliminated by increasing purge times.

BET surface area measurements performed by a commercial partner indicated that the ALD process did not significantly change the surface area of micron sized $\mathrm{LiCoO}_{2}$ particles coated with 2 or 4 cycles of $\mathrm{Al}_{2} \mathrm{O}_{3}$ ALD. This data indicates that our particles were not agglomerated by the ALD process (which would have decreased surface area), and that the ALD coating was smooth (since rough coatings would have increased the surface area).

\section{Battery Fabrication and Testing}

Most of the battery materials were characterized through coin cell testing in Prof. Se-Hee Lee's laboratory at CU, using a Li metal counter electrode. A full cell was also fabricated using 
DOE STTR DE-FG02-08ER86337: Topic “Nanotechnology”, Subtopic 12d - ALD NanoSolutions, Inc. "Novel ALD-coated Nanoparticle Anodes for Enhanced Performance Lithium-Ion Batteries"

ALD coated materials and tested. Additional fabrication and testing was performed by commercial partners.

Anodes were typically fabricated and tested as described here: Bare and ALD-coated graphite powder was mixed with PVDF binder using NMP in a mass ratio of 90:10. The slurry was then uniformally deposited onto $0.02 \mathrm{~mm}$ thick copper foil using a mechanical vacuum spreader. After the electrodes were dried at 120C in air, 1/2" cells were punched and then vacuum dried overnight. Prior to coin cell construction, the cells were placed into a glovebox and heated to 250C overnight on a hot plate. Heating of the electrodes has shown to greatly improve stability and capacity through the melting of the binder. Lithium metal was used as the counter electrode.

Cells were tested using an Arbin at constant current from 0.01 to 1.5 Volts. The cycling rate for the first two cycles were set at $\mathrm{C} / 10$ and was increased to $\mathrm{C} / 2$ for all subsequent cycles. Testing of bare and coated SG was run at both room temperature and at elevated temperature $(50 \mathrm{C})$. Room temperature results were inconclusive after 150 cycles due to the strong stability of SG. The increase in cycling temperature expedites the surface reactions and breakdown of the electrodes. After 80 cycles, the coated SG cells showed no noticeable improvement beyond the bare electrodes.

Cathode material testing was performed as described here: For the galvanostatic chargedischarge cycling, the composite electrode was prepared by spreading a slurry mixture of $\mathrm{LiCoO}_{2}$ powder (7-10 $\mu \mathrm{m}$, L106, LICO Technology), AB, and PVDF (83.0:7.5:9.5 weight ratio) on a piece of $\mathrm{Al}$ foil. Cells were assembled in an Ar-filled dry box and tested in a temperaturecontrolled oven. The galvanostatic charge-discharge cycling was performed with a twoelectrode 2032-type coin cell in the potential range of 3.3-4.5 V (vs. $\mathrm{Li}^{-} \mathrm{Li}^{+}$) at a current density of $0.1 \mathrm{C}$-rate $\left(14 \mathrm{~mA} \mathrm{~g}^{-1}\right)$ for the first two cycles and $1 \mathrm{C}$-rate for the subsequent cycles at room temperature.

Li metal foil was used as the counter electrode. 1.0 $\mathrm{M} \mathrm{LiPF}_{6}$ dissolved in a mixture of ethylene carbonate (EC) and DMC (1:1 v/v) was used as the electrolyte. Porous $20 \mu \mathrm{m}$ thick polypropylene (PP)/poly ethylene (PE)/PP tri-layer film was used as the separator. The EIS study was performed using a 1280C Solartron instrument. The AC impedance measurement was recorded using a signal with an amplitude of $5 \mathrm{mV}$ and frequency range from $20 \mathrm{kHz}$ to $5 \mathrm{mHz}$. After the $\mathrm{LiCoO}_{2} / \mathrm{Li}$ cells were charged to $4.5 \mathrm{~V}$ (vs. $\mathrm{Li} / \mathrm{Li}^{+}$) with a current density of $0.1 \mathrm{C}$-rate $\left(14 \mathrm{~mA} \mathrm{~g}^{-1}\right)$ and stabilized by resting for $6 \mathrm{~h}$, the AC impedance spectra were recorded at the open circuit voltage.

\section{ALD Films on Graphites}

\section{1. $\mathrm{Al}_{2} \mathrm{O}_{3} \mathrm{ALD}$ on Natural Graphite (NFG-HPM850, 5 $\mu \mathrm{m}$ )}

Bare and ALD-coated natural graphite (NG) anodes were tested in half cells using a Li metal cathode. Two ways of ALD coating the NG were investigated: 1) anodes were prepared from $\mathrm{Al}_{2} \mathrm{O}_{3}$ ALD coated NG powders, and 2) fabricated electrodes (containing graphite, acetylene black, and binder) were coated with ALD films. The charge/discharge cycling was preformed at elevated temperature $\left(50{ }^{\circ} \mathrm{C}\right)$.

Bare NG shows a steady decay in capacity as a function of the number of chargedischarge cycles, as shown in Figure 11a. NG particles coated with 5 cycles of $\mathrm{ALD}^{\mathrm{A}} \mathrm{O}_{2}$ on 
DOE STTR DE-FG02-08ER86337: Topic “Nanotechnology”, Subtopic 12d - ALD NanoSolutions, Inc. "Novel ALD-coated Nanoparticle Anodes for Enhanced Performance Lithium-Ion Batteries"

NG resulted in even poorer capacity retention than the bare NG. As shown in Figure 11b, the insulating character of the $\mathrm{Al}_{2} \mathrm{O}_{3}$ film could degrade the electronic conduction paths between particles and the current collector. Additionally, it should be noted that NG experiences $13 \%$ volume change during a charge-discharge cycle. Under repeated charge-discharge cycling, even a slight volume change of NG can disrupt the contacts between particles and current collectors, which can eventually accelerate degradation of electronic conduction paths.

Growing ALD films directly on the electrode solves the problem related to the electronic conduction path because all of the electrical contact points remain free from $\mathrm{Al}_{2} \mathrm{O}_{3}$ (Figure 11b.). As seen in the Figure 11a, growing 5 cycles $\mathrm{Al}_{2} \mathrm{O}_{3} \mathrm{ALD}$ directly on the already fabricated NG electrode dramatically improves the cycle performance. Excellent results were obtained both with and without the use of a $\mathrm{NO}_{2}$ /TMA pretreatment, which has been shown in the past to improve the coating conformality on graphitic substrates. The charge/discharge cycle retention for $5 \mathrm{Al}_{2} \mathrm{O}_{3}$ ALD cycles with $\mathrm{NO}_{2}$ /TMA functionalization shows $97.7 \%$ capacity retention up to 150 charge-discharge cycles with respect to the reversible capacity at the $3^{\text {rd }}$ charge-discharge cycle. At room temperature, $\mathrm{ALD} \mathrm{Al}_{2} \mathrm{O}_{3}$ coated $\mathrm{NG}$ also shows excellent cycle retention with negligible kinetic hindrance. Exceptionally good cycle life by directly coating electrode with ALD films is believed to be attributed to the electrochemically stable 'artificial' SEI of $\mathrm{Al}_{2} \mathrm{O}_{3}$ which protects the NG surface from undesirable decomposition reactions of the electrolyte.

Irreversible capacity during the first charge is related to the formation of SEI film that protects further decomposition of electrolyte at the subsequent charge. However, seeing a large irreversible reaction is undesirable because it implies not only a large impedance of the cell but also loss of large amount of the cathode materials. The intensity of the differential charge peak at $0.7 \mathrm{~V}$ during the first charge (inset in the figure 11c) indicates the irreversible reductive decomposition of the electrolyte decreases for NG coated with $\mathrm{ALD} \mathrm{Al}_{2} \mathrm{O}_{3}$ and further decreases if the $\mathrm{NO}_{2}$ /TMA functionalization is employed. Accordingly, the coulombic efficiency which is the ratio of discharge capacity to charge capacity significantly increases (Figure 11c).

In addition, the $\mathrm{Al}_{2} \mathrm{O}_{3}$ ALD coating on the formed graphite electrodes allowed propylene carbonate (PC) to be used in the electrolyte. PC is essential for operating Li- ion batteries at low temperatures due to its low melting point of $\sim 49{ }^{\circ} \mathrm{C}$. While PC is commonly used in primary $\mathrm{Li}$ cells, the instability of PC with graphite has forced the use of other less desirable electrolytes such as EC, for secondary Li-ion batteries. As observed by the long irreversible voltage plateau at $0.8 \mathrm{~V}$ in Figure 8 (dashed line), bare graphite is electrochemically exfoliated by PC-based electrolytes. In contrast, graphite electrodes coated with 5 cycles of $\mathrm{Al}_{2} \mathrm{O}_{3} \mathrm{ALD}$ reversibly reacts with $\mathrm{Li}$ without an irreversible plateau related to exfoliation. To our best knowledge, there are no reports of any other coating that can lead to the compatibility of graphite with PC-based electrolytes. This compatibility could be particularly important for the cold weather operation of hybrid and electric vehicles. 
DOE STTR DE-FG02-08ER86337: Topic “Nanotechnology”, Subtopic 12d - ALD NanoSolutions, Inc. "Novel ALD-coated Nanoparticle Anodes for Enhanced Performance Lithium-Ion Batteries"

a)

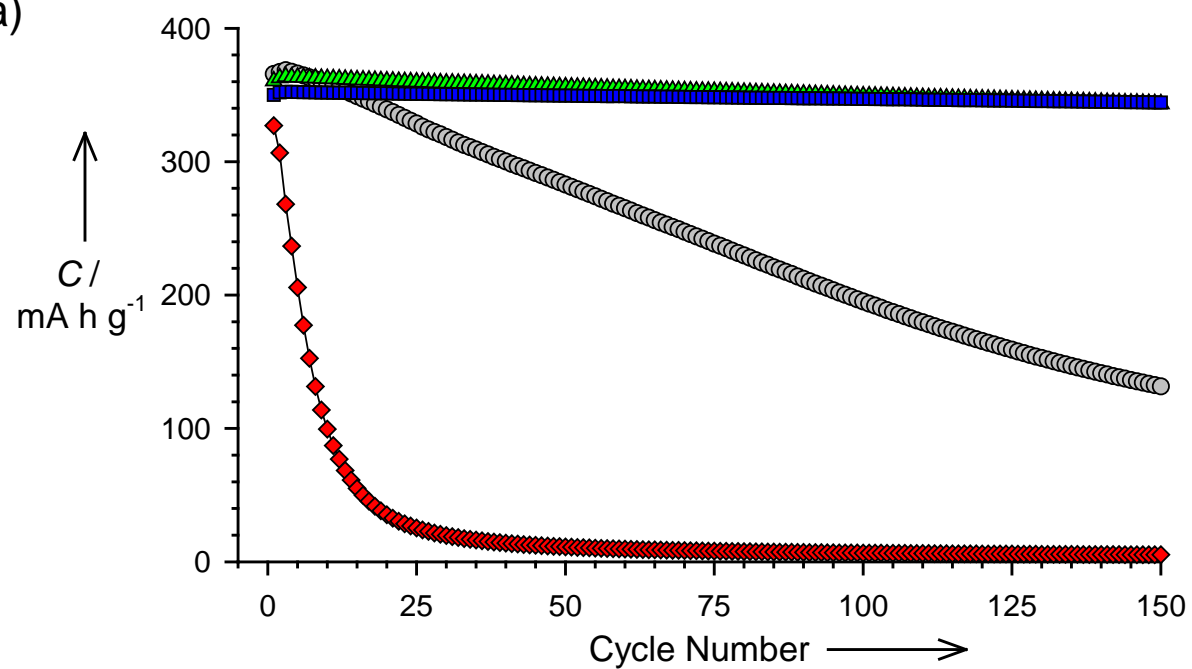

b)

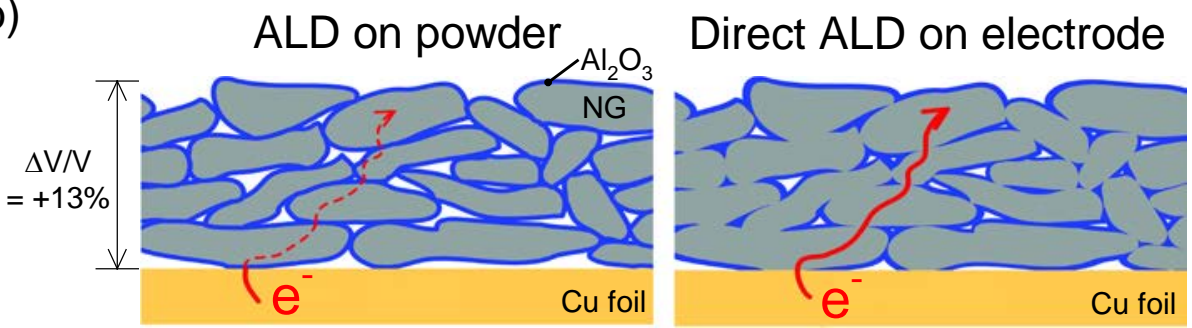

c)
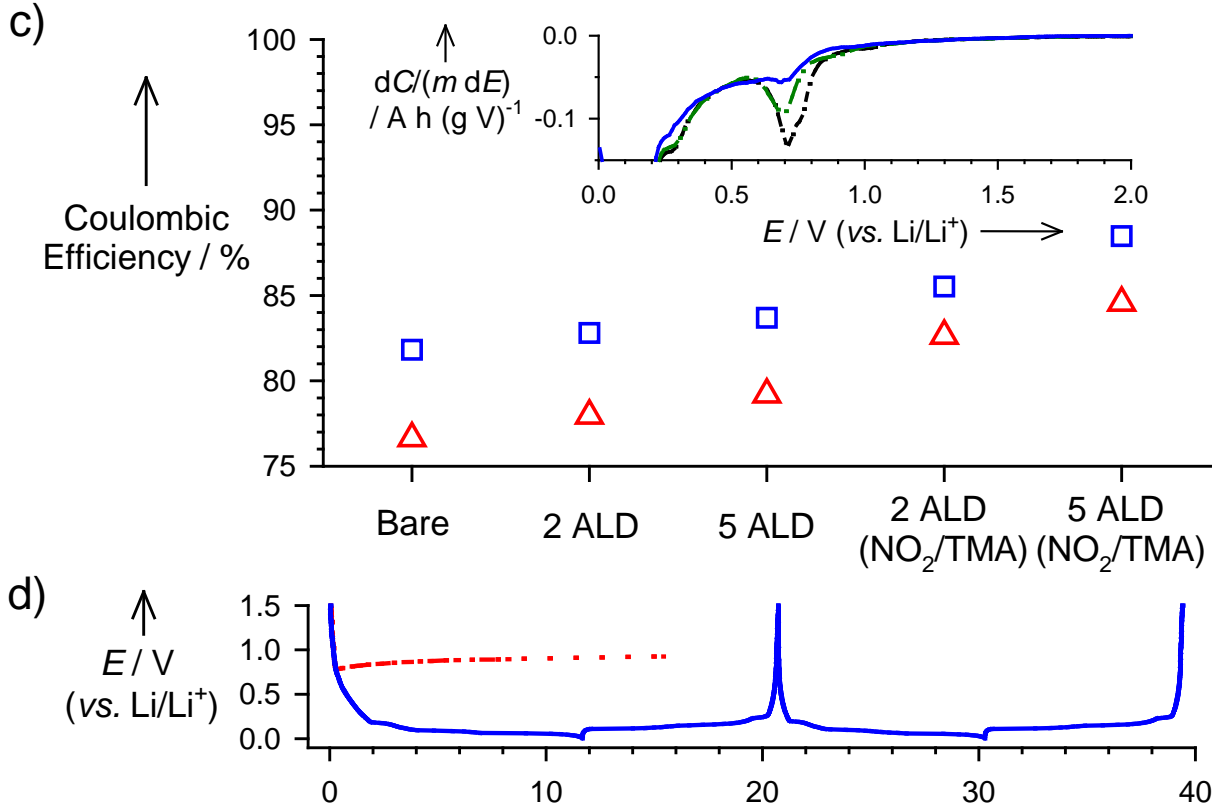

Figure 11. a) Cycle performance of bare NG (grey $t / h \mathbf{h r c l e s ) , ~} \mathrm{NG}$ with 5 cycles of $\mathrm{ALD} \mathrm{Al}_{2} \mathrm{O}_{3}$ on powder (red diamonds), NG with 5 cycles of $\mathrm{ALD} \mathrm{Al} \mathrm{O}_{3}$ on the electrode (green triangles), and NG with 5 cycles of $\mathrm{ALD} \mathrm{Al} \mathrm{O}_{3}$ on the electrode with $\mathrm{TMA} / \mathrm{NO}_{2}$ functionalization (blue squares) at 50 ${ }^{\circ} \mathrm{C}$. b) Schematic of NG composite electrodes prepared by ALD on powder and ALD directly on the electrode. c) Coulombic efficiency at the first cycle at room temperature (blue squares) and $50{ }^{\circ} \mathrm{C}$ (red triangles). Differential first charge voltage profiles of bare NG (dashed line), NG with 5 cycles of $\mathrm{ALD} \mathrm{Al} \mathrm{O}_{3}$ (dash-dotted line), and NG with 5 cycles of ALD $\mathrm{Al}_{2} \mathrm{O}_{3}$ on the electrode with TMA/NO functionalization (solid line) directly on electrode at room temperature are shown in the inset. d) Voltage profiles of bare NG (dashed line) and NG with 5 cycles of $\mathrm{ALD} \mathrm{Al}_{2} \mathrm{O}_{3}$ on the electrode with $\mathrm{TMA} / \mathrm{NO}_{2}$ functionalization (solid line) directly on electrode at room temperature when using $1 \mathrm{~mol}$ $\mathrm{dm}^{-3} \mathrm{LiPF}_{6}$ in PC as electrolyte.. 
DOE STTR DE-FG02-08ER86337: Topic “Nanotechnology”, Subtopic 12d - ALD NanoSolutions, Inc.

"Novel ALD-coated Nanoparticle Anodes for Enhanced Performance Lithium-Ion Batteries"

\section{ALD films on Superior Graphite}

The effects of $\mathrm{Al}_{2} \mathrm{O}_{3}, \mathrm{TiO}_{2}$ and TiN ALD coatings were investigated on micron size LBG8004 natural graphite from Superior Graphite. ALD coatings were performed at ALD NanoSolutions on $\sim 80 \mathrm{ml}$ quantities of the G5 graphite powder in a small test scale fluid bed reactor. The $\mathrm{Al}_{2} \mathrm{O}_{3}$ films were grown at $180{ }^{\circ} \mathrm{C}$ using trimethyl aluminum (TMA) and water. Films of 5 and 10 ALD cycles were deposited. In order to determine if deposition temperature had an effect on the growth of $\mathrm{TiO}_{2}$ and TiN, multiple temperatures were investigated for these films. $\mathrm{TiO}_{2}$ was deposited at both 150 and $325^{\circ} \mathrm{C}$ using $\mathrm{TiCl}_{4}$ and water. Again, films of 5 and 10 cycles were deposited at each temperature. TiN deposition was initially studied over a range of 180 to $475{ }^{\circ} \mathrm{C}$ using $\mathrm{TiCl}_{4}$ and $\mathrm{NH}_{3}$. The online residual gas analyzer data indicated that more reaction products ( $\mathrm{HCl}$ gas) were formed at higher temperatures, so subsequent coating runs were run at $475{ }^{\circ} \mathrm{C}$. However, the same data showed clearly that the deposition rate was much lower than for $\mathrm{Al}_{2} \mathrm{O}_{3}$ and $\mathrm{TiO}_{2}$. Therefore a 30 cycle run was performed in addition to the 5 and 10 cycle runs.

Since TiN was a new and unproven chemistry, additional analysis of the films was performed. Because of questions concerning the ability of TiN films to be evaluated for elemental composition by inductively coupled plasma atomic emission spectroscopy (ICP-AES), the coated graphite powders were analyzed by x-ray photoelectron spectroscopy. Although XPS is very sensitive for atomic composition, it can only analyze a sample's surface with a penetration depth of tens of nanometers, and therefore cannot give a overall elemental composition. Table 2 lists the elemental compositions in atomic percent for the TiN coated samples.

\begin{tabular}{l|c|c|c|c|c} 
Sample & $\mathrm{C}$ & $\mathrm{N}$ & $\mathrm{O}$ & $\mathrm{Ti}$ & $\mathrm{Cl}$ \\
\hline Uncoated Graphite & 97.6 & -- & 2.4 & -- & -- \\
5 cycles TiN & 98.3 & 0.1 & 1.1 & 0.2 & 0.2 \\
10 cycles TiN & 98.6 & 0.1 & 1.0 & 0.1 & 0.1 \\
30 cycles TiN & 97.5 & 0.5 & 1.3 & 0.5 & 0.1
\end{tabular}

The XPS analysis detected only small amounts of Ti and $\mathrm{N}$. While these results cannot be used to estimate a film thickness, the Ti and $\mathrm{N}$ signals did increase from $\sim 0.1$ to 0.5 at\% with increasing number of ALD cycles performed. However, the impurity level of chlorine was also found in similar quantities, likely present as unreacted Ti-Cl bonds in the film and as ammonium chloride resulting from the reaction between the ammonia and hydrogen chloride. It should also be noted that the oxygen contents for the coated samples were lower than the oxygen content of the uncoated graphite, indicating that the film was continuous enough to attenuate the signal of the underlying oxygen. Also, some of the oxygen detected likely resulted from the oxidation of the nitride film to an oxynitride film, as nitrides will often have an oxynitride film on the surface.

Half cell testing at CU revealed that none of these ALD cycle coatings had any significant effect on the capacity retention of this material over hundreds of charge/discharge cycles. These results are in some ways better than the coating of the NFG-HPM850 5 um NG powder, as $\mathrm{Al}_{2} \mathrm{O}_{3} \mathrm{ALD}$ coatings on those particles actually degraded their performance. Testing is also ongoing with one of our commercial partner, but we do not have results on these tests yet. Since improvements in performance on the NG above were only observed when the ALD coating was applied to the fabricated electrode, it will be interesting to find out if ALD coating anodes made from this LBG8004 can improve the performance of these already stable battery materials. 
DOE STTR DE-FG02-08ER86337: Topic “Nanotechnology”, Subtopic 12d - ALD NanoSolutions, Inc.

"Novel ALD-coated Nanoparticle Anodes for Enhanced Performance Lithium-Ion Batteries"

\section{ALD coatings on Conoco Phillips Cpreme G5}

Kilogram quantities of CP Cpreme G5 graphite $\left(\mathrm{d}_{50}=6.3 \mu \mathrm{m}\right)$ were coated with 5 and 10 cycles of $\mathrm{Al}_{2} \mathrm{O}_{3}$ and $\mathrm{TiO}_{2} \mathrm{ALD}$ at $180{ }^{\circ} \mathrm{C}$ in the pilot scale fluid bed reactor at ALD NanoSolutions. A123 Systems requested the ALD coatings on this material, in hopes that it would improve the stability of this G5 material, which currently does not exhibit sufficient stability in their applications. Testing is currently ongoing at both CU and at A123Systems. Again, we plan to also coat anodes in this fashion.

\section{4. $\mathrm{Al}_{2} \mathrm{O}_{3} \mathrm{ALD}$ on MCMB (aka Graphene)}

Mese-Carbon Micronbeads (MCMB) is a graphitic type material formed into micron size spheres. Although this material was well-regarded for it's stability in Li-ion batteries, it is apparently no longer produced. $\mathrm{Al}_{2} \mathrm{O}_{3} \mathrm{ALD}$ films did not improve the already quite stable performance of MCMB. Capacities of the ALD coated material were slightly lower, probably due to the insulating nature of the $\mathrm{Al}_{2} \mathrm{O}_{3}$. TEM images of bare and ALD coated were examined, but it was determined that nanometer and sub-nanometer thick ALD films could not be distinguished from the MCMB using TEM.

\section{E. ALD coatings on $\mathrm{MoO}_{3}$ particles and electrodes}

ALD coatings were grown on nano- $\mathrm{MoO}_{3}$ particles $(5-20 \mathrm{~nm}), \sim 5$ micron $\mathrm{MoO}_{3}$ particles, as well as on electrode fabricated from the nano- $\mathrm{MoO}_{3}$ particles. Previously, NREL researchers had obtained unprecedented reversible negative electrode capacity of $630 \mathrm{mAh} / \mathrm{g}$ for electrodes comprised of crystalline $\mathrm{MoO}_{3}$ nanoparticles. However, this impressive result could only be obtained when the electrodes were coated with a thin polymer electrolyte film. Furthermore, it was only observed with nano- $\mathrm{MoO}_{3}$, as the the micron size MoO3 capacity degraded rapidly, likely due to fracture of the $\mathrm{MoO}_{3}$ and long $\mathrm{Li}$ ion diffusion distances. It was though that ALD films would stabilize the nano- $\mathrm{MoO}_{3}$ but without the difficult electrophoresis process needed to fabricate these electrodes.

\section{a. Fabrication}

Nanospheres of Molybdenum Trioxide $\left(\mathrm{MoO}_{3}\right)$ were created using a Hot Wire Chemical Vapor Deposition (HWCVD) method at the facilities at the National Renewable Energy Lab (NREL). Unlike traditional HWCVD, the heated $0.5 \mathrm{~mm}$ thick Mo metal filament also acts as the source of the nanoparticles. The filament surface is oxidized and nanoparticles are deposited along a quartz collect chamber as the filament is heated with direct current. ( 16 amperes). TEM and XRD verify both the particle diameter averaging $15 \mathrm{~nm}$ and the uniform crystalline structure. The fully oxidized nanoparticles were then used as active material for negative electrodes. Acetylene black (AB) and polyvinylidene fluoride (PVDF) are used as the conductive additive and binder. The slurry is mixed using N-Methyl-2-pyrrolidone (NMP) to a predetermined consistency in a ratio of 70:10:20. After the slurry is spread onto copper foil and dried in a vacuum oven, the electrode is punched into $1 / 2$ " cells and assembled into a coin cell with lithium metal as the counter electrode. ALD coating occurred either during powder form or after electrode production. $\mathrm{Al}_{2} \mathrm{O}_{3}$ and $\mathrm{TiO}_{2} \mathrm{ALD}$ were performed on $\mathrm{n}-\mathrm{MoO}_{3}$ particles in the rotary ALD reactor at CU. 
DOE STTR DE-FG02-08ER86337: Topic “Nanotechnology”, Subtopic 12d - ALD NanoSolutions, Inc.

"Novel ALD-coated Nanoparticle Anodes for Enhanced Performance Lithium-Ion Batteries"

b. Testing

Completed cells are cycled using an Arbin system consisting of 24 channels. The cells were tested for AC Impedance, Coulombic efficiency, cycle stability, and total charge capacity. In order to maximize the capacity, the cells were tested using deep cycle charge and discharge from 0.001 to 3 Volts vs. Lithium metal. Cells underwent constant current profiles at an initial rate of $\mathrm{C} / 10$. On occasion, cycle rates would be increased to $\mathrm{C} / 2$ to assess the full impact of the ALD coating on stability under harsh conditions.

The ALD coating on nano- $\mathrm{MoO}_{3}$ showed great promise for increasing stability in materials which undergo a high volume expansion. Figure 12 depicts the preliminary results for the $\mathrm{MoO}_{3}$ research. The horizontal dotted line represents the theoretical capacity of $\mathrm{MoO}_{3}$. The bare $\mathrm{MoO}_{3}$ is stable for close to 30 cycles near theoretical capacity before rapid stability loss is noted. ALD coatings on particles show negative effects on both capacity and stability. For a thicker coating of 5-cycles, the $\mathrm{Al}_{2} \mathrm{O}_{3}$ coated nanoparticles clearly prevent the intercalaction of lithium into the lattice due to the low capacity. A thinner coating of $\mathrm{TiO}_{2}$ was more successful for initial capacities, matching values for the bare samples, however, the degradation of stability is associated with the large volume expansion of the nanospheres and the severing of electrical contact between the active material and the conductive additive of $\mathrm{AB}$.

Bare electrodes then coated with alumina ALD displayed the greatest improvement over bare samples. Cycled at C/2 (5 times the rate of the bare sample), the coated electrode is stable and fully reversible for nearly 40 cycles. Since the nanospheres expand radially upon intercalation of lithium, the spherical coating around each particle is inefficient at maintaining the necessary conductive path for both electrons. However, a very thin surface coating of a passivating material, such as $\mathrm{Al}_{2} \mathrm{O}_{3}$, allows not only for the conduction of ions but any vertical displacement of the electrode surface during expansion. 
DOE STTR DE-FG02-08ER86337: Topic “Nanotechnology”, Subtopic 12d - ALD NanoSolutions, Inc. "Novel ALD-coated Nanoparticle Anodes for Enhanced Performance Lithium-Ion Batteries"

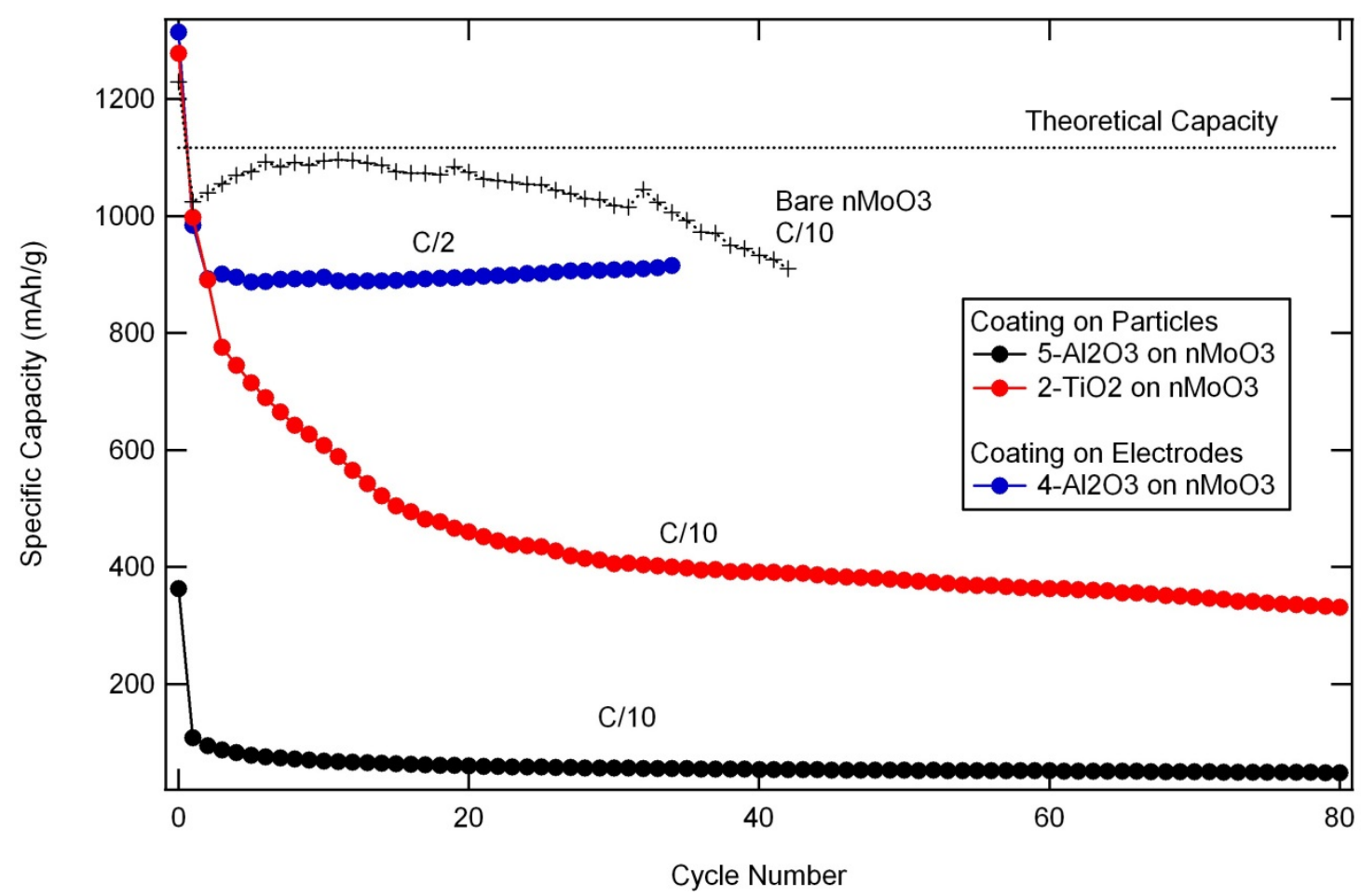

Figure 12 - Cycling data for nano- $\mathrm{MoO}_{3}$. Despite being cycled at a faster rate, the coated electrode is more stable than both the bare and the ALD coated particles.

These results are very impressive, as they demonstrate the ability of sub-nanometer thick ALD coatings to stabilize moderately high capacity/high expansion nanoparticle anodes. Ultrathin films such as these are required for nanopowders, as any thicker films would add unacceptable mass gains to such electrode nano-powders. Since ALD is a non-line-of-sight gas phase deposition technique, it is the only coating technique that we know of that can coat all the surfaces on the inside of a matrix of nanoparticles.

In discussions with NREL about the scale-up of $\mathrm{MoO}_{3}$ nanoparticles, it became clear that while $\mathrm{MoO}_{3}$ scale up may be possible, it is unlikely to be cost competitive with graphite. However, nano-graphite and nano-Si particles hold great promise if they can be stabilized, as discussed in the "technical approach" section earlier.

\section{F. ALD Films on Cathodes}

The promising results of ALD coatings on anodes demanded that we also investigate the effects of ALD coatings on the stability of cathode materials. Previous work has established that coatings may help prevent metal dissolution and help minimize reaction with the electrolyte solution. Furthermore, some of our commercial partners expressed interest in ALD coatings on cathodes.

\section{1. $\mathrm{Al}_{2} \mathrm{O}_{3}$ ALD on $\mathrm{LiCoO}_{2}$ particles and electrodes}

ALD coatings were deposited on the $\mathrm{LiCoO}_{2}$ particles and on the fabricated cathodes as described earlier for the anodes. ALD coatings on the particles included 2, 4, 6, 8, 10, 2050 
DOE STTR DE-FG02-08ER86337: Topic “Nanotechnology”, Subtopic 12d - ALD NanoSolutions, Inc.

"Novel ALD-coated Nanoparticle Anodes for Enhanced Performance Lithium-Ion Batteries"

cycles $\mathrm{Al}_{2} \mathrm{O}_{3}, 2$, 4, and 10 cycles $\mathrm{ZnO}$ ALD, and also $\mathrm{RuO}_{2}$ (although those have not been tested yet). $\mathrm{Al}_{2} \mathrm{O}_{3}$ coatings on electrodes consisted of 2 , 4, and 20 ALD cycles.

For the galvanostatic charge-discharge cycling, the composite electrode was prepared by spreading a slurry mixture of $\mathrm{LiCoO}_{2}$ powder (7-10 $\mu \mathrm{m}$, L106, LICO Technology), AB, and PVDF (83.0:7.5:9.5 weight ratio) on a piece of Al foil. Cells were assembled in an Ar-filled dry box and tested in a temperature-controlled oven. The galvanostatic charge-discharge cycling was performed with a two-electrode 2032-type coin cell in the potential range of 3.3-4.5 V (vs. $\left.\mathrm{Li} / \mathrm{Li}^{+}\right)$at a current density of $0.1 \mathrm{C}$-rate $\left(14 \mathrm{~mA} \mathrm{~g}^{-1}\right)$ for the first two cycles and $1 \mathrm{C}$-rate for the subsequent cycles at room temperature.

Li metal foil was used as the counter electrode. 1.0 $\mathrm{MLiPF}_{6}$ dissolved in a mixture of ethylene carbonate (EC) and DMC (1:1 v/v) was used as the electrolyte. Porous $20 \mu \mathrm{m}$ thick polypropylene (PP)/poly ethylene (PE)/PP tri-layer film was used as the separator. The EIS study was performed using a 1280C Solartron instrument. The AC impedance measurement was recorded using a signal with an amplitude of $5 \mathrm{mV}$ and frequency range from $20 \mathrm{kHz}$ to $5 \mathrm{mHz}$. After the $\mathrm{LiCoO}_{2} / \mathrm{Li}$ cells were charged to $4.5 \mathrm{~V}$ (vs. Li/Li ${ }^{+}$) with a current density of 0.1 C-rate $\left(14 \mathrm{~mA} \mathrm{~g}^{-1}\right)$ and stabilized by resting for $6 \mathrm{~h}$, the AC impedance spectra were recorded at the open circuit voltage.

The ability of ultrathin ALD coatings to change the stability of electrode materials in Li ion batteries was dramatically revealed by the capacity of half-cells prepared using either bare or $\mathrm{Al}_{2} \mathrm{O}_{3}$ ALD-coated $\mathrm{LiCoO}_{2}$ particles. Battery cathodes were prepared and cycled against a $\mathrm{Li} / \mathrm{Li}^{+}$anode near the threshold for $50 \% \mathrm{Li}$ extraction at $1 \mathrm{C}$-rate after the first two chargedischarge cycles. With respect to the third charge-discharge cycle, the $\mathrm{LiCoO}_{2}$ particles coated with 2 $\mathrm{Al}_{2} \mathrm{O}_{3}$ ALD cycles showed a $89 \%$ capacity retention after 120 chargedischarge cycles as shown earlier in Figure 13. In comparison, the bare $\mathrm{LiCoO}_{2}$ particles displayed only a $45 \%$ capacity retention after 120

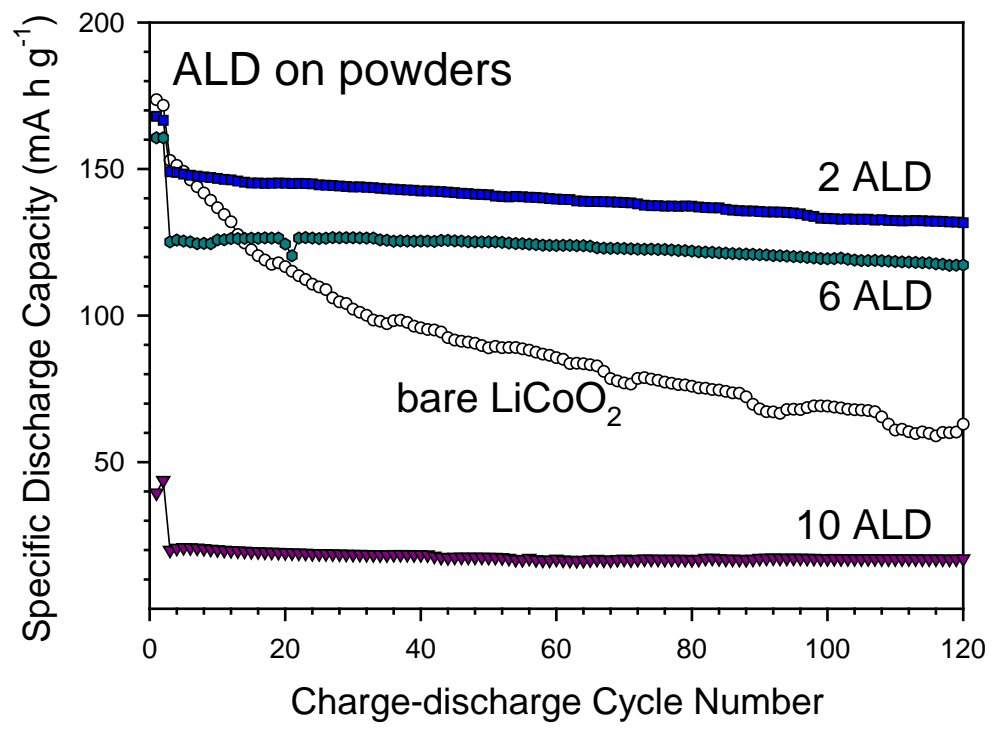
charge-discharge cycles.

The $\mathrm{Al}_{2} \mathrm{O}_{3}$ ALD may enhance the cycle performance of the half-cells by a number of mechanisms. The $\mathrm{Al}_{2} \mathrm{O}_{3}$ film may prevent the $\mathrm{LiCoO}_{2}$ particles from decomposing electrolyte and forming a solid-electrolyte interphase. Alternatively, the $\mathrm{Al}_{2} \mathrm{O}_{3}$ film may protect the $\mathrm{LiCoO}_{2}$ particles from corrosion by HF. Figure 4 also shows that $\mathrm{LiCoO}_{2}$ particles coated with 6 and $10 \mathrm{Al}_{2} \mathrm{O}_{3}$ ALD cycles showed lower specific capacities when run at a $1 \mathrm{C}$-rate after the first two charge-discharge cycles. This lower capacity is attributed to the slower $\mathrm{Li}^{+}$diffusion and restricted electron mobility through the insulating $\mathrm{Al}_{2} \mathrm{O}_{3} \mathrm{ALD}$ layer. 
DOE STTR DE-FG02-08ER86337: Topic “Nanotechnology”, Subtopic 12d - ALD NanoSolutions, Inc. "Novel ALD-coated Nanoparticle Anodes for Enhanced Performance Lithium-Ion Batteries"

Figure 14a shows the charge/discharge voltage profiles for electrodes fabricated with bare $\mathrm{LiCoO}_{2}$ powders or ALD-coated $\mathrm{LiCoO}_{2}$ powders using 2 ALD cycles. The polarization increases fast and the specific capacity drops rapidly versus charge/discharge cycle number for the electrodes prepared using the bare $\mathrm{LiCoO}_{2}$ powders. In contrast, the voltage profile and specific capacity do not change significantly for the electrodes made using the ALD-coated $\mathrm{LiCoO}_{2}$ powders.

Electrochemical impedance spectroscopy (EIS) analyses shown in Figure 14b was also utilized to evaluate the performance of electrodes prepared using bare $\mathrm{LiCoO}_{2}$ powders and $\mathrm{Al}_{2} \mathrm{O}_{3}$ ALD-coated $\mathrm{LiCoO}_{2}$ powders prepared using 2 ALD cycles. For the electrodes prepared using bare $\mathrm{LiCoO}_{2}$ powders, the first semicircle (\#) does not change much during cycling. In contrast, the radius of the second semicircle $(*)$ increases dramatically with the number of charge-discharge cycles. For the electrode prepared using $\mathrm{Al}_{2} \mathrm{O}_{3}$ ALD-coated $\mathrm{LiCoO}_{2}$ powders, the interface with the electrolyte is very stable and the semicircle holds its overall radius and shape even after 50 cycles. Although this interfacial stabilization has been demonstrated with $\mathrm{LiCoO}_{2}$ cathode particles with a diameter of $\sim 10 \mu \mathrm{m}$, we expect a similar effect of $\mathrm{Al}_{2} \mathrm{O}_{3} \mathrm{ALD}$ coatings on $\mathrm{LiCoO}_{2}$ nanoparticles on their interfacial stability.
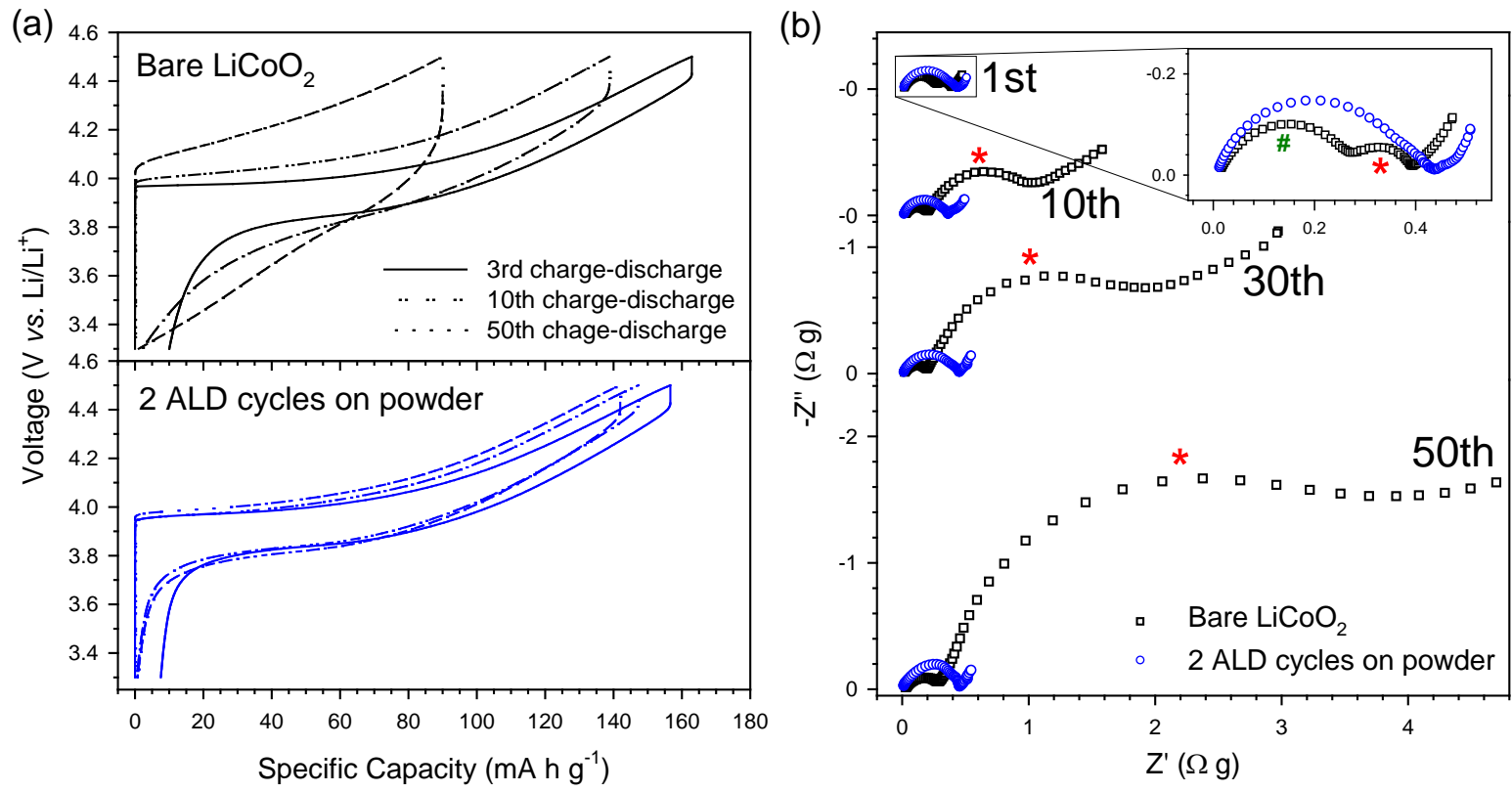

The enhanced capacity for the $\mathrm{LiCoO}_{2}$ particles coated with only 2 ALD cycles is exceptional. The $\mathrm{Al}_{2} \mathrm{O}_{3}$ ALD film thickness deposited using 2 ALD cycles is expected to be roughly $0.2-0.3 \mathrm{~nm}$, which represents only approximately one atomic layer of aluminum and oxygen. Still, this very minimal coating is able to dramatically alter the interaction of the $\mathrm{LiCoO}_{2}$ particles and the electrolyte forming the half-cell.

Additional experiments were conducted where the $\mathrm{LiCoO}_{2}$ particles were first used to make electrodes prior to ALD coating. ALD coatings of 2, 4, and 20 cycles were deposited on these electrodes. The 2 cycle ALD coated $\mathrm{LiCoO}_{2}$ also yielded improved stability over the bare $\mathrm{LiCoO}_{2}$, as shown in Figure 5 earlier. Unlike in the case of the graphite and MoO3 anodes, however, the results for the ALD coated $\mathrm{LiCoO}_{2}$ electrode were not as good as for the ALD coated $\mathrm{LiCoO}_{2}$ particles. 
DOE STTR DE-FG02-08ER86337: Topic “Nanotechnology”, Subtopic 12d - ALD NanoSolutions, Inc. "Novel ALD-coated Nanoparticle Anodes for Enhanced Performance Lithium-Ion Batteries"

\section{2. $\mathrm{ZnO}$ ALD on $\mathrm{LiCoO}_{2}$}

To compare $\mathrm{Al}_{2} \mathrm{O}_{3}$ ALD with other ALD materials, ZnO ALD was also grown on $\mathrm{LiCoO}_{2}$ powders. The $\mathrm{ZnO}$ ALD surface chemistry employs $\mathrm{Zn}\left(\mathrm{CH}_{2} \mathrm{CH}_{3}\right)_{2}(\mathrm{DEZ})$ and water as the reactants. The two self-limiting reaction sequences are:

$$
\begin{array}{lll}
\mathrm{ZnOH}^{*}+\mathrm{Zn}\left(\mathrm{CH}_{2} \mathrm{CH}_{3}\right)_{2} & \rightarrow & \mathrm{ZnO}-\mathrm{ZnCH}_{2} \mathrm{CH}_{3} *+\mathrm{CH}_{3} \mathrm{CH}_{3} \\
\mathrm{ZnCH}_{2} \mathrm{CH}_{3}{ }^{*} \mathrm{H}_{2} \mathrm{O} & \rightarrow & \mathrm{ZnOH}^{*}+\mathrm{CH}_{3} \mathrm{CH}_{3}
\end{array}
$$

$\mathrm{ZnO}$ ALD was deposited on $\mathrm{LiCoO}_{2}$ particles using 2, 4, and 10 ALD cycles. The stability of electrodes prepared using these $\mathrm{ZnO}$ ALD-coated $\mathrm{LiCoO}_{2}$ particles was then compared with electrodes fabricated using the $\mathrm{Al}_{2} \mathrm{O}_{3}$ ALD-coated $\mathrm{LiCoO}_{2}$ particles.

The electrodes fabricated with $\mathrm{ZnO}$ ALD-coated $\mathrm{LiCoO}_{2}$ particles showed larger overpotentials at larger charge-discharge cycle numbers and no improvement in cycle performance as compared with electrodes fabricated with the bare $\mathrm{LiCoO}_{2}$ powders. The atomic fraction of $\mathrm{Zn}(\mathrm{Zn} /(\mathrm{Zn}+\mathrm{Co}))$ and $\mathrm{Al}(\mathrm{Al} /(\mathrm{Al}+\mathrm{Co}))$, before cycling and after 10 chargedischarge cycles was also obtained using XPS. The atomic fraction of Zn dramatically decreases from 0.49 before cycling to 0.01 after 10 charge-discharge cycles. In contrast, the atomic fraction of $\mathrm{Al}$ maintains the same value within experimental error. The initial atomic fraction of Al was 0.55 before cycling and was 0.53 after 10 charge-discharge cycles. These XPS measurements indicate that the $\mathrm{Al}_{2} \mathrm{O}_{3} \mathrm{ALD}$ film is electrochemically more stable than the $\mathrm{ZnO}$ ALD film. It seems that the $\mathrm{ZnO}$ coating may have dissolved.

\section{ALD on commercial $\mathrm{LiCoO}_{2}$}

Based on the promising results obtained on our $\mathrm{LiCoO}_{2}$, a commercial partner requested that we coat their $\mathrm{LiCoO}_{2}$ in larger scales. Kilogram batches of commercial $\mathrm{LiCoO}_{2}$ were coated with $\mathrm{Al}_{2} \mathrm{O}_{3}$ ALD films in the pilot scale fluid bed reactor at ALD NanoSolutions. Electrodes were fabricated and tested by our commercial partner. The results of the ALD coated materials were compared to uncoated $\mathrm{LiCoO}_{2}$ as well as to $\mathrm{LiCoO}_{2}$ with a proprietary coating currently used by this commercial partner to stabilize this material.

As with the other $\mathrm{LiCoO}_{2}$ mentioned above, the ALD coated cathode was significantly more stable than the uncoated $\mathrm{LiCoO}_{2}$. Our partner mentioned "clearly improved cycle stability at 4.5V", and "clearly improved rate performance", and also noted that there was no change in the BET surface area, which indicated a smooth coating. The cathodes made from $\mathrm{LiCoO}_{2}$ powder coated with 4 cycles of $\mathrm{Al}_{2} \mathrm{O}_{3} \mathrm{ALD}(\sim 0.5 \mathrm{~nm})$ also compared well with the coating used by this commercial partner. They noted that the ALD film performed as well as their currently used coating, but with a much lower Al content. Being such a thin coating, the ALD coating requires less precursor and also adds less mass to the electrode (and while this difference in mass increase may be small in this case, it becomes much more important for smaller particles).

$\begin{array}{lllllllllll}\text { Sample } & \text { BET } & \text { QC } & \text { QD } & \text { Qirr } & \text { rate } & \text { rate } & \text { rate } & \text { f } & \text { f } & \text { rate } \\ \text { Description } & \mathrm{m}^{2} / \mathrm{g} & \mathrm{mAh} / \mathrm{g} & \mathrm{mAh} / \mathrm{g} & \% & 1 \mathrm{C} & 2 \mathrm{C} & 3 \mathrm{C} & \mathbf{( 0 . 1 C )} & \mathbf{( 1 C )} & 4.5 \mathrm{~V} \\ \text { uncoated } & 163.3 & 2.69 & 95.1 & 92.4 & 89.7 & 24.0 & 46.1 & 95.4 & 2.0\end{array}$


DOE STTR DE-FG02-08ER86337: Topic “Nanotechnology”, Subtopic 12d - ALD NanoSolutions, Inc. "Novel ALD-coated Nanoparticle Anodes for Enhanced Performance Lithium-Ion Batteries"

\begin{tabular}{|c|c|c|c|c|c|c|c|c|c|}
\hline 2 cycles ALD & 0.330 & 162.5 & 159.2 & 2.05 & 96.1 & 93.9 & 92.5 & 7.3 & 13.2 \\
\hline 4 cycles ALD & 0.326 & 163.0 & 159.7 & 1.98 & 96.0 & 93.9 & 92.6 & 3.2 & 6.8 \\
\hline $\begin{array}{l}\text { Reference } \\
\text { Coating }\end{array}$ & & & & & & & & $2-4$ & $4-8$ \\
\hline
\end{tabular}

Table 3.

$\mathrm{f}=$ rate of capacity loss at 4.5V (in \%) per 100 cycles (extrapolated) obtained from cycles \#8,\#30 and \#9, \#31

\section{F. Full Cell ALD coated battery}

While half cell testing of anodes and cathodes provides a controlled way to evaluate new battery materials and coatings, full cell battery testing is needed to really validate performance of these electrodes. Full cell testing can reveal unexpected interactions between the electrodes and also shows deficiencies that may not be apparent during half cell testing using an almost unlimited Li ion source. (Our commercial partners also asked for this testing also.)

Using the most promising materials evaluated during phase I testing, a battery was fabricated from $\mathrm{LiCoO}_{2}$ powder coated with 2 cycles of $\mathrm{ALD} \mathrm{Al}_{2} \mathrm{O}_{3}$ combined with a NG anode which was coated with 2 cycles of $\mathrm{ALD} \mathrm{Al}_{2} \mathrm{O}_{3}$. The weight ratio of $\mathrm{LiCoO}_{2} / \mathrm{NG}$ was $\sim 1.4$. 1.0 mol dm ${ }^{-3}$. $\mathrm{LiPF}_{6}$ dissolved in a mixture of ethylene carbonate (EC) and dimethyl carbonate (DMC) (1:1 v/v) was used as electrolyte. Cells were assembled in an Ar-filled dry box and tested in a temperature-controlled oven. The galvanostatic charge-discharge cycling was made with a two-electrode 2032-type coin cell. $\mathrm{LiCoO}_{2} / \mathrm{NG}$ full cells were cycled in the 3.30-4.45 V at $0.1 \mathrm{C}$-rate $\left(14 \mathrm{~mA}\left(\mathrm{~g} \text { of } \mathrm{LiCoO}_{2}\right)^{-1}\right.$ ) for the first two cycles and $1 \mathrm{C}$-rate for the subsequent cycles

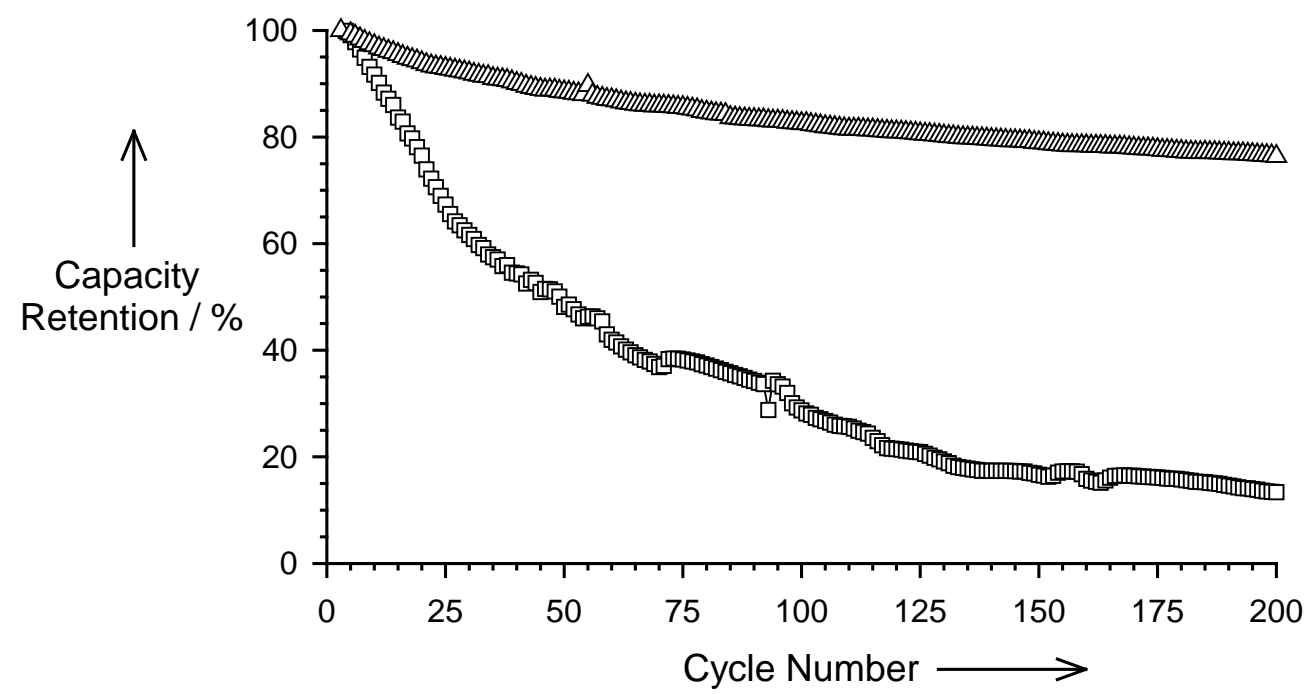

The ALD coated cell shows significantly enhanced cycle performance as compared to the uncoated cell. The capacity of the battery fabricated using the bare battery materials was down to $<15 \%$ after 200 charge/discharge cycles at $1 \mathrm{C}$, while the ALD coated cell retained over $75 \%$ of its original capacity. 
DOE STTR DE-FG02-08ER86337: Topic “Nanotechnology”, Subtopic 12d - ALD NanoSolutions, Inc.

"Novel ALD-coated Nanoparticle Anodes for Enhanced Performance Lithium-Ion Batteries"

\section{G. Economic Evaluation}

The economics of scaling up the coatings on commercial battery materials were calculated for two commercially promising ALD coatings developed during phase I. The ALD coating of $\mathrm{LiCoO} 2$ particles was of interest to our commercial partner Umicore, and it was found that the added cost of ALD coatings can be done at a reasonable added cost. Similar economics were obtained for a roll-to-roll ALD process for scaling up the promising ALD coatings of fabricated anodes made from commercial natural graphite particles.

\section{ALD on $\mathrm{LiCoO}_{2}$ particles}

Process economics were calculated for a 4 cycle coating of $\mathrm{Al}_{2} \mathrm{O}_{3}$ ALD on commercial $\mathrm{LiCoO}_{2}$ particles, since this ALD coating provided the best performance in testing by this commercial partner. Calculations are based on a 10,600 mt/yr fluidized bed particle ALD process (as requested by our partner) to produce a sub-nanometer thick $\mathrm{Al}_{2} \mathrm{O}_{3}$ films on $\mathrm{LiCoO}_{2}$ particles with a surface area of $\sim 0.35 \mathrm{~m}^{2} / \mathrm{g}$ and a tap density of $\sim 2.7 \mathrm{~g} / \mathrm{cm}^{3}$. Particles are processed in a $0.92 \mathrm{~m}$ diameter fluidized bed reactor. The ALD precursors are trimethylaluminum (TMA) and water $\left(\mathrm{H}_{2} \mathrm{O}\right)$. Methane is the byproduct of both reactions. The plant is operated $88 \%$ of the time with a $2300 \mathrm{~kg}$ batch of composite particles produced every 2.3 hours.

The Total Permanent Investment (TPI) for this plant is estimated at \$1.1 million. Primary Variable Operating Cost factors include the cost of $\mathrm{Al}_{2} \mathrm{O}_{3}$ at $\$ 121$ / kg, which results in a coating coast of $\$ 0.08 / \mathrm{kg}$ of coated powder and utility costs of $\mathrm{N}_{2} /$ electricity at $\$ 0.71 / \mathrm{kg}$ of coated powder. Fixed Operating Cost is primarily labor and overhead and is estimated at $\$ 0.87 / \mathrm{kg}$ (165\% total overhead for operators at $\$ 40,000 / y r$ salary in U.S. midwest). Working capital is estimated as $18 \%$ of TPI and the plant is depreciated using 7 year modified accelerated cost recovery. Plant capacity is estimated to be 50\% in Yr 1, 75\% in Yr 2, and 90\% in Yr 3 and thereafter. To obtain a 33\% Return on Invest (ROI), the coated particles are sold with an added cost of $\$ 0.97 / \mathrm{kg}$. The Payback Period (PBP) is 3 years, with cash flow generated in Yr 3 of $\$ 1,141,000$.

2. ALD on Graphite Anodes in a Roll-to-roll process

The economics of coating fabricated graphite anodes in a roll to roll fashion were estimated based on the successful results of ALD coating anodes fabricated from 5 um natural graphite particles. Although there are significant technical differences in how to perform ALD in a rollto-roll fashion vs. a fluid bed reactor, the coating economics are actually fairly similar for large volume commercial production. The economics were based on natural graphite with a surface area of $\sim 1 \mathrm{~m}^{2} / \mathrm{g}$ and a tap density of $0.84 \mathrm{~g} / \mathrm{cm}^{3}$, coated with 4 cycles of $\mathrm{Al}_{2} \mathrm{O}_{3}$ ALD at a scale of $4600 \mathrm{mt} / \mathrm{yr}$. The roll-to-roll process assumed a $1 \mathrm{~m}$ wide metal foil substrate with a $200 \mathrm{um}$ thick layer of graphite, moving at $1 \mathrm{~m} / \mathrm{s}$ web speed. Capital costs for this roll to roll system were estimated at \$ 4 million, which is significantly higher than the cost of a fluid bed system. Higher precursor and labor costs were more than offset by lower utility costs. In the end, the added cost for coating of graphite electrodes with ALD is still only $\$ 1.10 / \mathrm{kg}$ of coated graphite, based on a 3 year PBP and 33\% ROI. Compared to typical electrode materials costs, the added cost to stabilize the graphite with ALD films still only add a small fraction of the total electrode materials cost at these industrial production scales. We believe that the value added to these electrodes will more than offset the added cost of the ALD coating. 